\title{
Ismeretlen Reguly-térképek és -térképvázlatok? Adalékok és kérdések Reguly kartográfiai munkáival kapcsolatban
}

\author{
Márton Mátyás
}

DOI: https://doi.org/10.30921/GK.71.2019.6.2

Absztrakt: 2019 „Reguly-év” volt: születésének 200. évfordulója. Az ünnepi megemlékezéseken, konferenciákon az ÉszakiUrál és vidékének jeles magyar utazója, Reguly Antal (1819 - 1858) életmúvéhez kapcsolódó kutatások, értékelések sorából nem hiányoztak a térképészeti (terepen végzett, nem múszeres felmérési és kartográfiai/térképszerkesztöi) vonatkozású eredményeit bemutató és elemzó elöadások sem.

A szerzố ebben a dolgozatában Reguly „Az Északi-Urál ... térképe...” címü müvének két változatával - a Szentpéterváron készült kéziratos, árnyékolásos domborzatrajzú, valamint az ugyancsak ott litografált csíkozásos domborzatábrázolású térképpel - kapcsolatban felmerülô több kérdésre keres választ, és rámutat további kutatások szükségességére.

[Mindkét német nyelvú térkép teljes címe: „Ethnographisch-geographische Karte des Nördlichen Ural Gebietes entworfen auf einer Reise in den Jahren 1844 und 1845 von Anton v. Reguly. St. Petersburg 1846.”, magyarul: „Az Északi-Urál vidékének néprajzi-földrajzi térképe, amelyet Reguly Antal 1844-és 1845-ben tett utazása során tervezett. Szentpétervár 1846."]

Abstract: 2019 was a "Reguly Year": the 200th anniversary of his birth. At the festive memorials and conferences, researches and evaluations related to the oeuvre of Antal Reguly (1819 - 1858), the prominent Hungarian traveler of the Northern Ural and its region, did not miss the lectures presenting and analyzing his cartographic work (both field, non-instrumental survey and cartographic/map editing work).

In this paper, the author seeks to answer several questions about the two versions of Reguly's "Map of the North Ural ..." and points to the need for further research. The two versions are: a manuscript, shaded relief map and a lithographed, hachured relief map. Both maps were made in St. Petersburg.

[Full address of both German-language maps: „Ethnographisch-geographische Karte des Nördlichen Ural Gebietes entworfen auf einer Reise in den Jahren 1844 und 1845 von Anton v. Reguly. St. Petersburg 1846.", in English: "Ethnographic-geographic Map of the Northern Ural Region made by Antal Reguly during his travels in 1844 and 1845. St. Petersburg 1846."]

Kulcsszavak: térképtörténet, függőleges megvilágítású domborzatárnyékolás, ferde megvilágítású domborzatárnyékolás, csíkozásos térkép, ismeretlen térképek

Keywords: cartography history, vertical hill shading, oblique hill shading, hachured map, unknown maps

A 2019-es esztendô újra „Reguly-év” volt. Születésének 200. évfordulójára több konferenciát, megemlékezést szerveztek, előadások hosszú során elemezték, értékelték a Reguly-életmú különböző, fóleg a nyelvészet, a folklór, az antropológia, a néprajz és a földrajz területéhez sorolható részeit, illetve ezen tudományágak ma is folyó, kapcsolódó kutatásait is megismerhettük, nem egy esetben külhoni elôadók révén.

Szúkebb szakterületünknek, a térképészetnek sem kell szégyenkeznie, nagyszerú szakmunka megjelenésével büszkélkedhet ebbôl az alkalomból. A négynapos zirci konferencián, éppen Reguly születésnapján mutatta be Gulyás Zoltán „Reguly Antal térképészeti munkássága” címú könyvét. A kétnapos érdi konferencián pedig (a szerzô betegsége miatt) Gercsák Gábor tolmácsolásában hangzott el Márton Mátyás „Az ELTE Térképtudományi és Geoinformatikai Tanszékének szerepe
Reguly térképészeti munkássága értékeinek feltárásában”, illetve Gulyás Zoltán „Reguly Antal kartográfiai szemlélete" címú elôadása.

Mind az érdi konferenciára való felkészülésem, mind Gulyás Zoltán könyve recenziójának megírása azzal járt együtt, hogy igyekeztem újraolvasni a témában az elmúlt, immár több mint 110 esztendő alatt született, térképészeti vonatkozású, nem túl nagyszámú munkákat. Az elmélyülés hozta magával, hogy néhány olyan kérdés fogalmazódott meg (vagy újra megfogalmazódott) bennem, amelyekre adandó válaszokkal jelenleg még adós a térképtudomány.

\section{Észrevételek Reguly szentpétervári, 1846-os kéziratos és kinyomtatott térképeihez}

A kéziratos térképpel kapcsolatban már a korábban, a Geodézia és
Kartográfiában megjelent dolgozatomban feltételeztem, hogy az valószínúleg a Reguly által szerkesztett - tartalmilag összefüggó és egymáshoz pontosan illeszkedô 16 negyedrét ívbôl álló kéziratos térképtervnek, a rajzoló által elkészített, árnyékolt domborzatábrázolású, tisztázati kéziratos anyaga (Márton 2009). A két fél lappá összedolgozott $(2 \times 8$ ív anyagát tartalmazó részből fölépülő) térkép felhasználásával készült utóbb az MTA-ban két példányban ma is ôrzött, de ugyancsak Szentpétervárott litografált és kinyomtatott, csíkozásos domborzatrajzú mú.

Gulyás Zoltán doktori értekezésében (2016: 49) és könyvében (2019: 60) is megemlíti, hogy az árnyékolt domborzatú kéziratos térkép 16 álló helyzetú téglalapra osztott, amelyek sarokpontjait jól láthatóan megjelölték, és ezeket vékony vonallal is összekötötték. Annak kapcsán hozza ezt szóba, hogy 
korábban feltételeztem azt is, hogy nem egy kôrôl nyomtatták ki a litografált térképet: „Az sem elképzelhetetlen, hogy a teljes térképet nem egy kôről, hanem több - négy vagy nyolc darabban sokszorosították. Ezt alátámasztani látszik, hogy az MTA-térképen határozott tónusbeli különbség mutatkozik négy térképnegyed színei között, valamint az is, hogy ezeken belül páronként pl. a vízfelületeket kísérô bandok szélessége eltérō (Márton 2009: 27)." Most végzett vizsgálataim egyértelmúvé tették, hogy szelvénypáronként litografálták és nyomtatták a térképet, és egészen biztosan kizárom, hogy ez 16 darabban, azaz szelvényenként történt volna!

Itt hívom fel a figyelmet arra, hogy Gulyás felfedezésével szemben kétféle, méretében nem túlságosan eltérô szelvényezés rajza található az árnyékolt domborzatú térképen! Elsố gondolatom az volt, hogy ezek egyike a kinyomtatott (csíkozásos domborzatrajzú) térképével egyezô (azaz a litografálást segítette), a másik pedig, gondoltam, talán az általam már korábban is felvetett elméletet támasztja alá: sarokpontjai a 16 negyedrét ívból álló elsô, valóban Reguly által készített kéziratra utalhatnak. Megvizsgálva azonban a szelvényezéseket, meg kellett állapítanom, azok egyike sem egyezik a kinyomtatott, majd vászonra kasírozott térkép szelvényeivel! Viszont bármelyik lehet a 16 negyedrét íves anyag sarokpontjait jelölő, amely térképtervnek - ezt egyre inkább bizonyítottnak látom -, léteznie kell. Meg kell jegyezni azt is, hogy az egyik szelvényezés határoló vonalai és sarokpontjai halványabbak a másiknál (1. ábra).

A kérdés - hogy létezett-e a Reguly által készített 16 íves térkép-elôterv biztos megválaszolása azonban csak szentpétervári kutatásokkal lehetséges, így is csak akkor, ha megkerülnek a térképlapok. A kéziratos, summerolt térképet Szentpéterváron, az Orosz Földrajzi Társaság Könyvtárában oorzik. Ott érdemes tehát keresni a hiányzó 16 „láncszemet”, amely összeköti Reguly terepi térképvázlatait, az árnyékolt domborzatrajzú kéziratos térképével.

Gulyás munkáiban (2016: 42; 2019: 56) utal rá, hogy még nem volt módja eredetiben tanulmányozni a nevezetes kéziratot. Mi Magyarországon csak Szíj Enikô, az ELTE BTK Magyar Nyelvtudományi és Finnugor Intézete Finnugor Tanszékének nyugalmazott docense szívességébôl, a birtokában lévô két fényképfelvétel segítségével adhattunk leírást, illetve elemezhettük a térképi tartalmat. A térképre vonatkozó múszaki-fizikai adatok (papírtípus; pontos méretek; két félból álló feldolgozás, amelynek alsó fele a hajtás mentén elszakadt stb.) a szakirodalomból, Vlagyiszlav Georgijevics Karelintől1 ${ }^{1}$ (1991) származnak.

\footnotetext{
1 Karelin, Vlagyiszlav Georgijevics [ ${ }^{*} 1932$. augusztus 8. Kamenszk-Uralszkij (ma Orosz ország, Szverdlovszki terület)]: az Orosz Földrajzi Társaság, az Uráli Honismereti Társaság tagja, a múszaki tudományok kandidátusa, Reguly-kutató, életmúvének oroszországi népszerúsítője. Kezdeményezésére nevezték el hivatalosan, valamint jelölték meg orosz és magyar nyelvú táblákkal 1990. július 30-án
}

Gulyás Zoltán szóbeli tájékoztatása szerint a restaurálás eloott álló térkép most nem, de várhatóan jövőre már vizsgálható lesz, és tervezi is a szentpétervári utat, már csak azért is, hogy a jelenleginél jobb felbontású fényképeket készíthessen a további kutatásokhoz. Szerencsés lenne ezt a látogatást összekötni a feltételezett 16 térképszelvény felkutatásával!

Felvetôdik az a kérdés is: Vajon az íráskép alapján egyértelmú-e, hogy a kéziratos térkép névírását Reguly Antal készítette? Megvizsgáltam ezt a kérdést az Ob torkolatközeli vidékének neveit összevetve a „Karte Nro. V.” terepi térképvázlaton és a kéziratos térképen. Számomra egyértelmú a nem válasz. Csak írásszakértô tudná biztonsággal eldönteni, hogy a terepi vázlatok nevei, illetve a kéziratos, summerolt térkép nevei ugyanazon kéztôl, nevezetesen Reguly kezétôl származnak-e. De a vizsgálódásom eredményeképpen az is adódott, hogy a summerolt térképet rajzoló, bárki legyen is az, a rendezetlen terepi vázlat alapján egy lépésben aligha készíthette el a névrajzot, sốt az egyéb - például vízrajzi - elemek rajzolatát sem. Ez ismét csak azt erôsíti meg, hogy Regulynak ezt megelôzóen valóban el kellett készítenie a 16 negyedrét ívből álló „térkép-előtervet”, terepi munkájának egyfajta letisztázását: a gyưjtött névváltozatok szúrését, illetve a vízrajzi, a domborzati és más rajzi elemeknek „határozott földirati

a 1711 m magas Reguly-csúcsot a Sarki-Urálban a szovjet-magyar „csúcsnévadó” tudományos expedíció tagjai (Gulyás 2017).

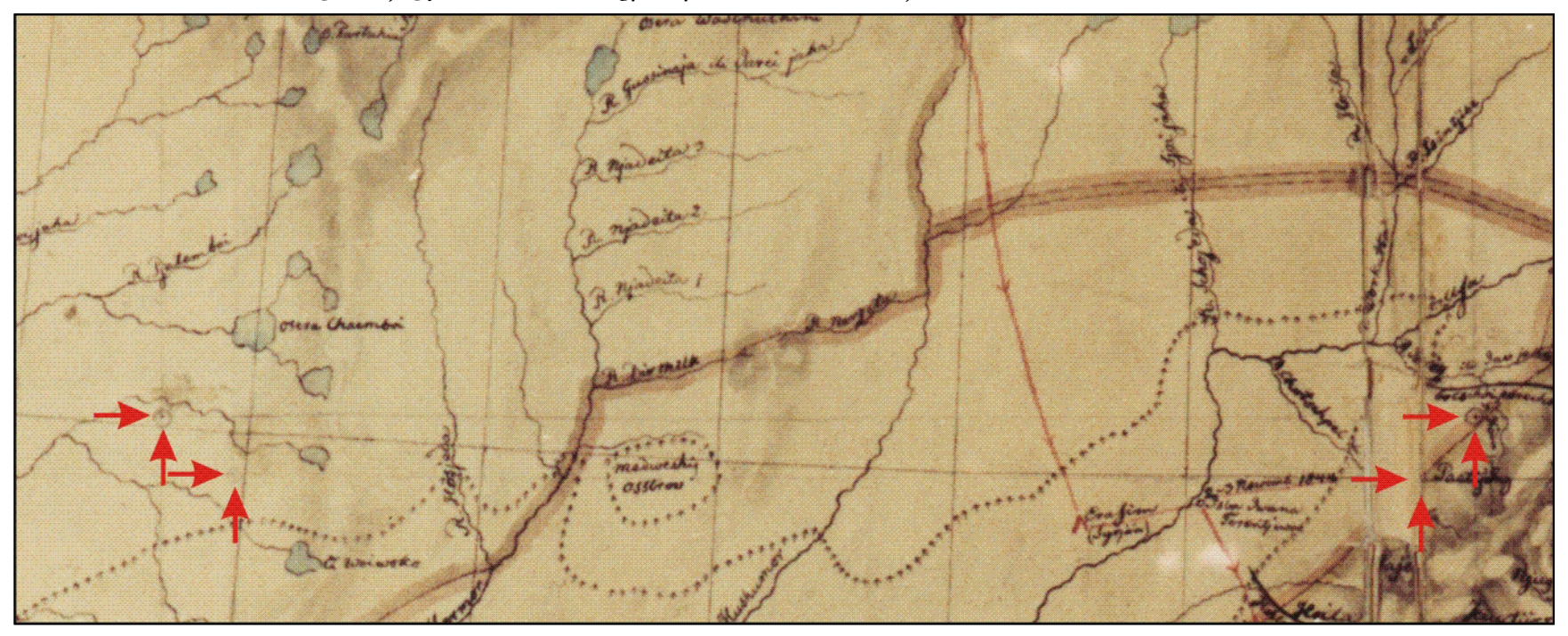

1. ábra. Piros nyilak mutatnak rá a sarokpontokra. A sarokpontokon átmenô halvány egyenes vonalak a szelvényhatárok 
formát" kellett adni, és csak ezt követôen, ennek felhasználásával készülhetett el a summerolt változat.

\section{Párhuzam a Reguly-féle kéziratos térkép és a Perczel-glóbusz árnyékolt domborzatábrázolása között}

Az elóbb idézett dolgozatomban (Márton 2009) „orosz stílusú” domborzatábrázolásról beszélek, amit sajnos Gulyás is átvesz, mind a doktori értekezésében (2016: 49), mind a könyvében (2019: 57).

A Reguly-térképen - pontosan fogalmazva - függóleges megvilágítású domborzatárnyékolást alkalmazott a térképrajzoló. Gulyás Zoltán feltételezi, hogy a domborzatrajz nem Reguly munkája. Magam is így vélem. [Ezzel a domborzatábrázolási stílussal kezdő térképszerkesztőként találkoztam a Kartográfiai Vállalatnál az 1970es évek második felében. Több, kiválóan summeroló, a Szovjetunióból származó (pongyolán fogalmazva „orosz”) kolléganőm egyike mutatta meg ezt a módszert, de a gyakorlatban leginkább a ferde megvilágitású árnyékolást használtuk a vállalatnál. Innen származik tehát a megtévesztő „orosz” jelzó alkalmazása.] A hegygerincet „keskeny fehér platóként” ábrázoló domborzatárnyékolást széles körben alkalmazták ebben az idōben. A Reguly térképével gyakorlatilag egykorú Perczel-glóbuszon (1862) is ilyen módon készült a domborzatrajz (2. ábra).

Részemrôl megtévesztô és szerencsétlen volt tehát ezt a megnevezést használni, különösen a Laszkij-féle ${ }^{2}$ térkép (Karta Permszkoj gubernii - A Permi kormányzóság térképe) domborzatrajzával összemosva!

\section{Reguly térképének pontosságáról}

Reguly Antal két elôadást tartott 1856 ban (!), azaz majd' 10 esztendôvel térképe elkészítése után, a Magyar Tudós Társaságban (azaz az akadémián).

A Történelemtudományi Osztályon 1856. június 2-án tartott elôadóülésen elhangzottakról szóló szakirodalomból kiemelendônek gondolom, hogy Reguly elsố »Elôadása végén összehasonlítást tesz „eredeti rajzolatjai” és a Péterváron készített térképe között. Megállapítja, hogy azok az „elmozdítások”, amelyeket a földiratilag meghatározott „rámákba” való igazítással tett, nagyon csekélyek voltak. Az urali expedíció térképével való összehasonlítás pedig meg fogja mutatni, hogy az „egykorú földképíró” eszközeivel $\mathrm{s}$ igyekezetével mennyire mehetett

\footnotetext{
2 Laszkij (?): járási földmérô. Oroszország területén a Permi kormányzóságban múködött a 19. század közepén. Nevét az idézett, általa „szerzett”, kéziratos térképrôl ismerjük, amelyet 1843-ban Reguly a kormányzótól kapott meg, és használta uráli kutatóútja során, majd saját térképének elkészítésekor is. Ezt ma az MTA Könyvtár és Információs Központ Kézirattára ốrzi. A térkép digitális fakszimile változatát folyóiratunkban Gulyás Zoltán (2019c) mutatja be.
}

a földrajzilag meghatározott pontokkal rendelkezô térképésszel szemben.«... Ilyen módon tesz különbséget a ",mathematikailag múködő" mérnök és a „kartográf” között. A földmérô abszolút fekvésú, földrajzi hosszúság és szélesség által meghatározott pontokra támaszkodhatik, a „rajzoló országisme” csak olyan pontokra, amelyeknek geoetnográfiai tényezók tekintetébôl van határozott értékük és csak mint részek, az egészhez való viszonyukban nyújtanak határozott biztonságot« (Borbély 1955: 240).

A fentieket összegezve tehát elmondhatjuk, hogy a helyszíni terepvázlatokat egy térképpé összerakva csak alig-alig kellett azokat átszerkesztenie Regulynak.

A június 30-án tartott akadémiai előadásán immár az urali Hofmann ${ }^{3}$. expedíció - számára Reden által megküldött - térképét vetette össze a sajátjával, megállapítva, hogy „a különbséget oly csekélynek találta, hogy az csak 2-3 földrajzi mérföldet tesz ki. Ez a különbség a nagy távolságok arányában igen jelentéktelen. A két térkép tartalmának összehasonlító vizsgálata pedig azt mutatja, hogy az Ural expedíció térképezési munkálatai néhány

\footnotetext{
3 Hofmann, Ernst Reinold von (Gofman, Ernszt Karlovics) [ ${ }^{*}$ Paistel, Lívföldi kormányzóság (ma Paistu, Észtország) 1801. január 08. (20.), †Dorpat (ma Tartu, Észtország), 1871. május 11. (23.)] orosz utazó, geológus. 1847-48-ban, majd 1850-ben az általa vezetett uráli területeken földtani kutatást és múszeres helymeghatározó méréseket végzô expedíció fontos forrásként használja Reguly térképét (Paistel 1820).
}

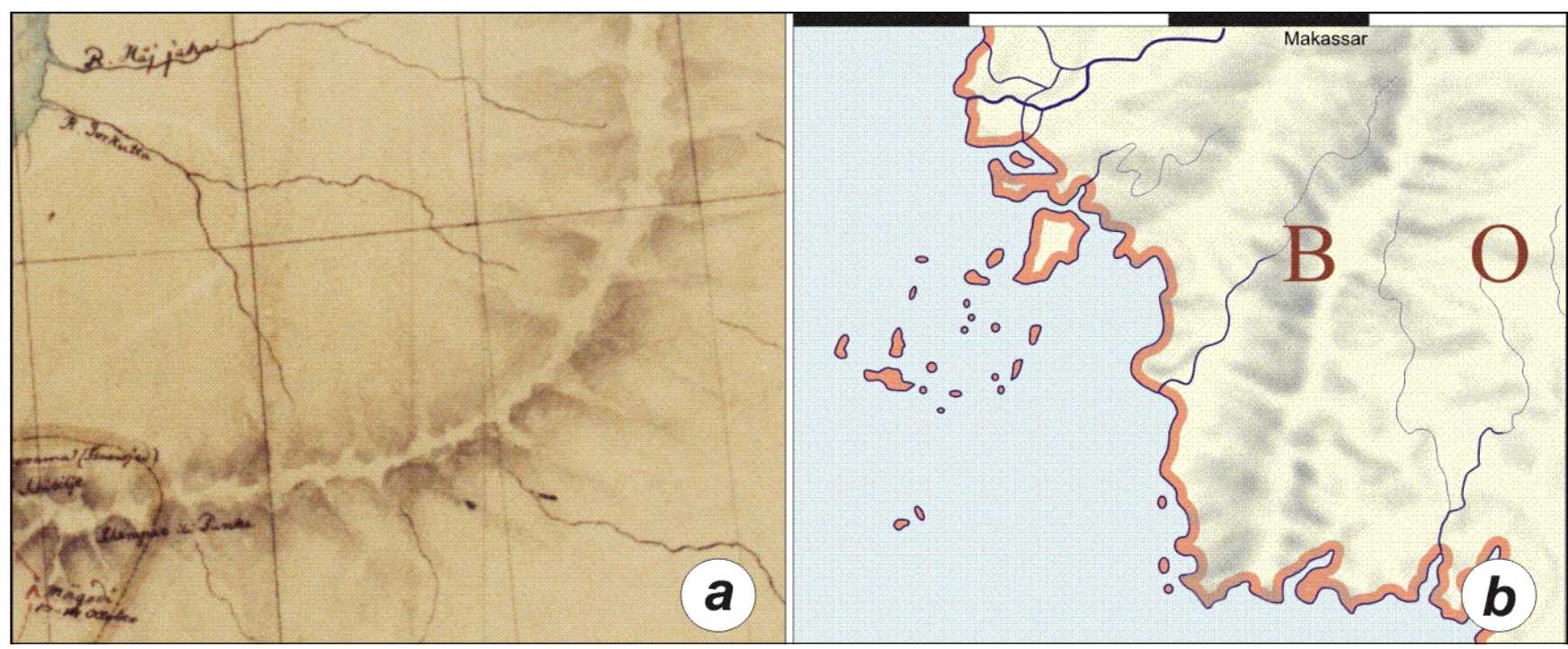

2. ábra. Függóleges megvilágítású domborzatárnyékolás: a) Reguly summerolt térképén; b) a Perczel-glóbuszon (részletek) 
új forráscsatornától eltekintve, semmi új adatot nem szolgáltattak" (Borbély 1955: 241).

Értelmezve az elmondottakat: mivel 1 földrajzi mérföld $=7421,6 \mathrm{~m}$, az eltérések a Hofmann-expedíció felmérése és a Reguly-térkép között 22,5 km alattiak, akkor, amikor a térkép É-D-i irányú, mintegy 12 foknyi kiterjedése kb. $1340 \mathrm{~km}-\mathrm{t}$ tesz ki!

A szakirodalomban többször találkozunk azzal a megjegyzéssel, hogy az akadémiai előadások után Reguly nem foglalkozott többet a térképével. Igaz lehet. De késôbb látni fogjuk, hogy az Urál térképi ábrázolásával azonban még foglalkozott!

\section{Reguly levelei nyomán felvetôdó kérdések}

\section{Szentpétervár, 1847.}

január 21. (február 2.)

Idézzünk fel egy mondatot Reguly Köppenhez ${ }^{4}$ írt levélből: „sziveskedjék bensố köszönetemet átadni Savič professzor úrnak, aki oly nagy készséggel segített nekem térképem elsố vázlatában" (Pápay 1906: 368).

Reguly térképe „elsố vázlatá”-ról szól itt. Az elsố vázlat nem igen lehetett a kéziratos, summerolt térkép, hiszen az már egy letisztázott mú, és nem vázlat. Így tehát csak a 16 negyedrét íven készült kéziratról (szelvényezett térképtervrôl?) lehet szó! Ebben nyújthatott segítséget - akár kritikai észrevételei közlésével is - Alekszej Nyikolajevics Szavics5.

Fontos a dátum! Még csak éppen elkészült a kéziratos, árnyékolt domborzatrajzú térkép, a „vállalkozás” elsô fele, a levél pedig annak második feleként értelmezhetô. Hiszen a munka elvégzésére, amely „csak egy geográfiai kártya szerkesztésében és ennek commentációjában áll..." - ahogy azt

\footnotetext{
4 Köppen, Peter von (Kjoppen, Pjotr Ivanovics); [ Harkov (ma Harkiv, Ukrajna)] 1793. február 19. (március 02.), †Karabagh [Krím] 1864. május 23. (június 04.): geográfus, statisztikus, történész. 1839-től a szentpétervári akadémia tagja. A neves meteorológus, Wladimir Peters Köppen édesapja.

5 Szavics, Alekszej Nyikolajevics ["Puskarevka (ma Puskarivka, Ukrajna) 1810. február 25. (március 9.), †Blagodaty (Oroszország, Tulai terület), 1883. augusz tus 15. (augusztus 27.)]: orosz csillagász egyetemi tanár, 1862-tôl a szentpétervári akadémia tagja.
}

Reguly Toldynak ${ }^{6}$ írja (Borbély 1955: 236) - az egyik felkérố a Hofmannexpedíciót szervezô - csak 1845-ben megalakult - Orosz Földrajzi Társaság nevében éppen Köppen volt, Sztruve mellett.

\section{Pest, 1856. november 30.}

Öt hónap telt el Reguly második akadémiai elôadása óta...

Reden $^{8}$ bárónak, a bécsi Császári és Királyi Földrajzi Társaság (der kaiserlich-königlichen Geographischen Gesellschaft in Wien) egyik alelnökének írt Reguly-levél tartalmát próbálom értelmezni az alábbiakban, a Pápay (1906: 368-370) által közzétett változat alapján. A levél így kezdődik:

„Tisztelt Uram! Kicsiny térképemre vonatkozólag meg kell jegyeznem, hogy intencióimat a terepalakulatok tekintetében, részben saját technikai járatlanságom következtében, részben pedig rajzolóm ${ }^{9}$ korlátolt felfogása miatt, korántsem érhettem el.

Ez okból vagyok bátor nézeteimet az egész északi Ural fóalakulatairól, amelyeket föltüntetni szerettem volna, a következőkben röviden körvonalozni, azzal a szándékkal, hogy azokat, amenynyire lehetséges, helyesbítsem.”

Két szót emeltem ki az idézetben: a térképére vonatkozó jelzôt, a kicsinyt és a rajzolómat, akinek a munkájával elégedetlen volt Reguly.

Vajon melyik Reguly kicsiny térképe? A szentpétervári térképkészítés

\footnotetext{
6 Toldy Ferenc (született: Schedel Ferenc) (*Buda, 1805. augusztus 10., †Budapest, 1875. december 10.): irodalomtörténész, kritikus, egyetemi tanár, a Kisfaludy Társaság igazgatója, majd másodelnöke. Az MTA tagja, 1835-61 között titkára. 1845-ben létrehozza a Reguly Társaságot, amelynek célja egy Reguly album kiadásával annyi pénz elôteremtése mely a kutató további kétévi ellátását biztosítja, hogy a gyújtött anyagokat feldolgozhassa és úgy térhessen vissza Magyarországra.

7 Sztruve, Vaszilij Jakovlevics [Struve, Friedrich Georg; Altona (ma Hamburg része) 1793. április 15.-Szentpétervár, 1864 november 23.] német származású orosz csillagász, aki I. Miklós cár felkérésére a híres Pulkovói Obszervatórium építésének szakma irányítója, majd igazgatója.

8 Reden, Friedrich Wilhelm Otto Ludwig Freiherr von [ Weidlingshausen-kastély (ma Dörentrup, Lippe járás, Észak-Rajna-Vesztfália), 1804. február 11., †Wien, 1857. december 12.)]: politikus, statisztikus, szakíró

9 Márton (2009) korábbi tanulmányában téved, amikor ezt a rajzolót a csíkozásos domborzatábrázolású térképhez rendeli. A továbbiak majd megvilágítják, hogy a két rajzoló más-más személy.
}

időszaka óta eltelt 10 esztendő! Miért kanyarodik vissza hozzá? Egyáltalán arról beszél?

Ha figyelmesen elolvassuk a levelet, csak arra a következtetésre juthatunk, hogy Reguly Reden számára egy új, egy általunk eddig ismeretlen kis térképet készített rajzolója segítségével az Urálról! Ehhez fúz magyarázatokat, és ad részletes felszínalaktani leírást levelében, a továbbiakban...

„Ez az a kép - összegzi Reguly a levél vége felé -, amelyet én az északi Ural jellemzố fốalakulatairól saját tapasztalatom után nyertem. Nagy örömömre szolgálna, ha Ön, mélyen tisztelt Uram, kis térképemen a javításokat, amenynyire lehetséges, ebben az értelemben eszközölhetné. Mindenek elôtt pedig helytelen rajta a Harova hoinak és a Longot és Scsucsja között elterülô hegyhátaknak túlságosan sötét szinezése, úgyszintén az Uralgerinc is a Kuta forrásaitól a Meneszentiig; távolabb nyugatra, a Kara és a Szilova közötti sötét rész is a nagy térképem szerint helyreigazítandó." Szerintem a nagy térkép az 1846-os, Szentpéterváron litografált és kinyomtatott, csíkozásos térkép. (Reden aligha ismerhette a summerolt kéziratot.) Vajon elôkerülne-e ez az ismeretlen Reguly-térkép a Redenhagyaték vizsgálatával?!

Érdekes kérdést vet fel a Reguly Redenhez írt levelének legvégéról vett másik részlet is. Nem is egyet, mindjárt kettőt: „Részben azért, hogy bemutassam elsố geográfiai munkámban követett eljárásomat, részben a helynevek könnyebb olvashatósága végett 5 térképvázlatot mellékeltem. Az utolsón az Obnak a Vojkar melletti nyugati elốre hajlását, valamint a Meneszenti fekvését helyesebbnek fogja találni, mint a nagy térképemen. A szamojéd föld is jobban van föltüntetve, minthogy akkor a tengerpart helytelen berajzolásával még nem voltam megtévesztve" [Pápay: 370]. Ugyanott az 1) lábjegyzet: „Mind az öt megvan a M. Tud. Akadémia kézirattárában."

Az elsố kérdés tehát: Valóban megvannak-e (másolatban) a Redenhez írt levél térképmellékletei is, vagy csak az öt eredeti terepi vázlatról beszél Pápay?! A másolatokról nem tudunk. Ám ezek talán fellelhetôk Bécsben. Reden báró a bécsi Földrajzi Társaság 
egyik alelnöke volt. Levelezését talán a Földrajzi Társaság Könyvtárában ôrzik. Érdemes lenne ennek is utánajárni!

A második kérdést egy fél mondat veti fel: ,...,minthogy akkor a tengerpart helytelen berajzolásával még nem voltam megtévesztve." Azaz a levélben Reguly kritikát fogalmazott meg a forrásként használt, a tengerparti viszonyokat ábrázoló térképpel kapcsolatban.

Magától Regulytól (Köppenhez, még tíz évvel korábban - az orosz idōszámítás szerint - 1847 januárjában írt leveléból) tudjuk, hogy „az északi vonalat Ivanov kormányos fölvétele után" rajzolta meg, ,aki fölvételt készített a Pecsora torkolatától az Ob torkolatáig terjedô tengerpartról" (Pápay 1906: 356). Oly nagyon helytelen lenne emiatt Reguly térképe? Összevetve a rajta szereplő partvonal rajzolatát egy mai térképével (Cartographia Világatlasz, Bp. 2001, 66. o.: Kelet-Európa, részlet) (3. ábra), számomra ez a megjegyzés nem igazán értelmezhető! Az Ob-torkolat teljesen a helyén van. Ez tehát aligha befolyásolhatta a folyó ábrázolását a kinyomtatott nagy térképen. Igaz, hogy az Ob-öböl szélesebb, mint a valóságban, de a nagy mértékú eltérés kelet felé jelentkezik, így aligha van hatással a szamojédek bemutatására. Talán, ha valaki más gondolati megközelítéssel vizsgálja ezt a kérdést, mint én, választ tud majd adni erre a kérdésre.

\section{Összefoglalás}

A Reguly-szakirodalom újraértékelése nyomán fölvetôdik a gondolat, hogy több, ma még ismeretlen

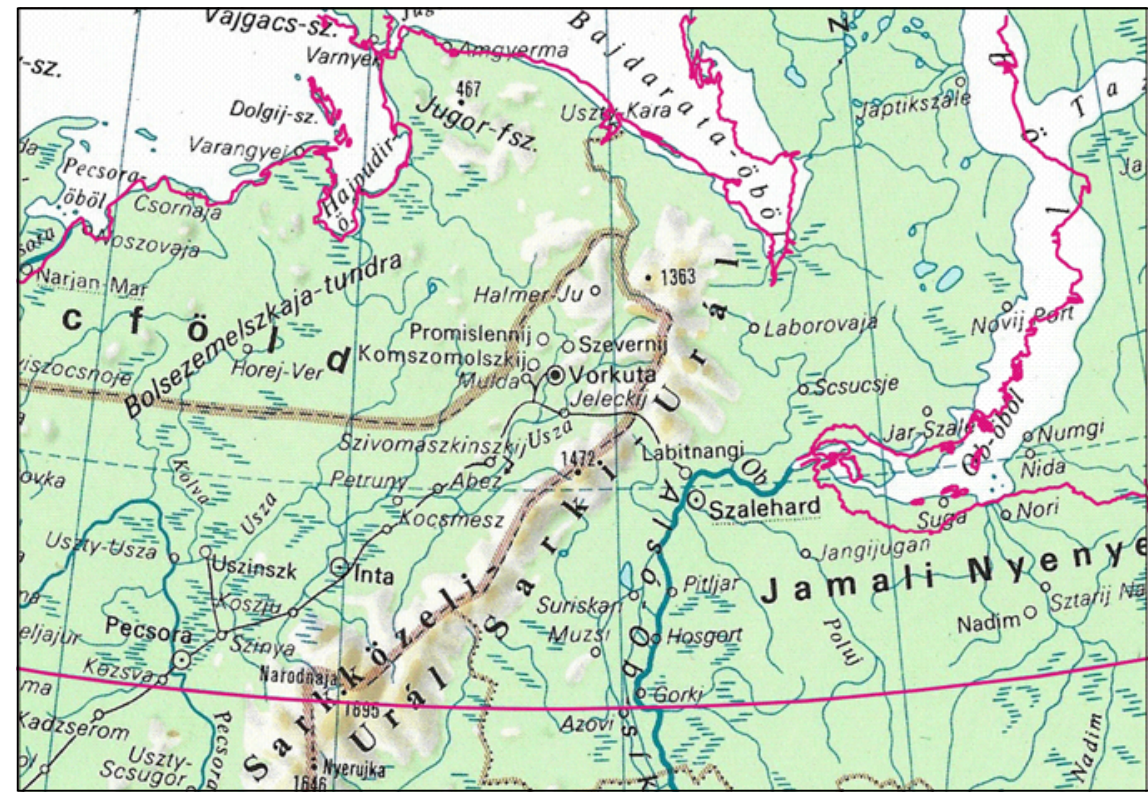

3. ábra. A Reguly-térkép partvonalrajza a Cartographia Világatlasz térképére vetítve az északi szélesség 65 fokos vonalát illesztésképpen használva

Reguly-térkép és -térképvázlat létét feltételezzük. Ezek felkutatása, vagy a felvetések elutasítása további kutatásokat igényel Szentpéterváron és - feltehetôen - Bécsben is.

\section{Irodalomjegyzék}

Borbély Andor 1955. Reguly Antal térképének szerepe az Észak-Ural megismerésében. Földrajzi Közlemények, III. (LXXIX.) kötet, 1955. 3. szám, pp. 231-242.

Gulyás Zoltán 2016. Reguly Antal térképészet munkássága. Doktori értekezés. Kézirat Budapest, p. 114

Gulyás Zoltán 2017. Vlagyiszlav Georgijevics Karelin 85 éves. Finnugor Világ, XXII/3. pp. 26-27.

Gulyás Zoltán 2019. Reguly Antal térképészeti munkássága. Reguly Antal Múzeum és Népi Kézmüves Alkotóház, Zirc

Gulyás Zoltán 2019b. Szóbeli közlés

Gulyás Zoltán 2019c. A Laszkij-féle permi térkép digitális fakszimile változata. Geodézia és Kartográfia, 2009/2. pp. 14-19. DOI: https://doi.org/10.30921/GK.71.2019.2.3
Karelin, Vlagyiszlav Georgijevics 1991. Hegynevek Reguly Antal Északi-Urál térképén. Földrajzi Közlemények, CXV. (XXXIX.)/1-2.pp. 37-47.

Márton Mátyás 2009. Reguly Antal és az ÉszakiUral térképe. Geodézia és Kartográfia, 2009/11. pp. 20-30.

Paistel 1820. A Livföldi kormányzóság térképén 1820-ban, https://ru.wikipedia.org/ wiki/Файл:Карта_Лифляндской_губернии.jpg (Utolsó elérés: 2019. 09. 30.)

Pápay József 1906. Reguly Antal urali térképe Földrajzi Közlemények, XXXIV/9. pp. 349370, A Köppen akadémikusnak írt levél pp. 356-368., A Reden bárónak írt levél pp. 368-370.

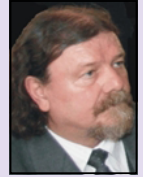

\section{Dr. Márton Mátyás professor emeritus, az MTA doktora}

ELTE Térképtudományi és Geoinformatikai Tanszék matyi@map.elte.hu 